This is an author produced version of a paper published in Journal of Dairy Research. This paper has been peer-reviewed..

Citation for the published paper:

Åkerstedt, M., Persson Waller, K. and Sternesjö, Å. (2007) Haptoglobin and serum amyloid A in relation to the somatic cell count in quarter, cow composite and bulk tank milk samples. Journal of Dairy Research. 74: 3, 198-203. ISSN: 0022-0299.

$$
\text { http://dx.doi.org/10.1017/S0022029906002305 }
$$

Access to the published version may require journal subscription. Published with permission from: Cambridge University Press

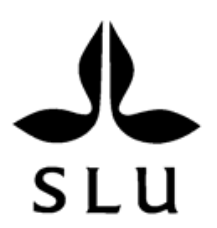

Epsilon Open Archive http://epsilon.slu.se 


\title{
Haptoglobin and serum amyloid $A$ in relation to the somatic cell count in quarter, cow composite and bulk tank milk samples
}

\author{
Maria Åkerstedt ${ }^{1}$, Karin Persson Waller ${ }^{2,3}$ and Åse Sternesjö ${ }^{1 *}$ \\ ${ }^{1}$ Department of Food Science, PO Box 7051, Swedish University of Agricultural Sciences, SE-750 07 Uppsala, Sweden \\ ${ }^{2}$ Department of Pigs, Poultry and Ruminants, National Veterinary Institute, SE-751 89 Uppsala, Sweden \\ ${ }^{3}$ Department of Clinical Sciences, PO Box 7054, Swedish University of Agricultural Sciences, SE-750 07 Uppsala, Sweden
}

Received 28 June 2006 and accepted for publication 25 October 2006

\begin{abstract}
Milk somatic cell count (SCC) is the gold standard in diagnosis of subclinical mastitis, and is also an important parameter in quality programmes of dairy cooperatives. As routine SCC analysis is usually restricted to central laboratories, much effort has been invested in the search for alternative biomarkers of mastitis and milk quality, including the presence in the milk of the acute phase proteins (APP), haptoglobin ( $\mathrm{Hp}$ ) and serum amyloid $\mathrm{A}(\mathrm{SAA})$. The aim of this study was to investigate relationships between $\mathrm{Hp}, \mathrm{SAA}$ and SCC in quarter, cow composite, and bulk tank milk samples. Cows $(n=165)$, without any clinical signs of disease or abnormalities in the milk or udder, from three different dairy farms, were used. Cow composite milk samples from all cows delivering milk at the sampling occasion were taken once in each herd. In one of the farms, representative quarter milk samples $(n=103)$ from 26 cows were also collected. In addition, bulk tank milk samples from 96 dairy farms were included in the study. Samples were analysed for Hp, SAA and SCC, and relationships between the parameters were evaluated at quarter, cow and tank milk levels using Chi-square analysis. Milk samples were categorized according to their SCC, and the presence, or no presence, of SAA and $\mathrm{Hp}$, based on the detection limits of the screening methods $(0.3 \mathrm{mg} / \mathrm{l}$ and $1.0 \mathrm{mg} / \mathrm{l}$ for SAA and Hp, respectively). $\mathrm{Hp}$ and SAA were found in milk at quarter, cow composite and bulk tank levels. A large proportion (53\%) of the animals had detectable milk concentrations of APP, and SAA was detected more frequently, and at higher concentrations than $\mathrm{Hp}$, regardless of sample type. SAA was detected in as many as $82 \%$ of the bulk tank milk samples. Significant relationships were found between Hp, SAA and SCC at quarter and cow composite milk levels, but only between SAA and SCC at bulk tank milk level. Detectable levels of APP were more common at high SCC.
\end{abstract}

Keywords: Subclinical mastitis, biomarkers.

Besides being an animal welfare problem, mastitis affects the yield, composition and processing properties of the milk, with negative impact on the final dairy product quality. Clinical mastitis can, in most cases, easily be detected, but diagnosis of subclinical mastitis requires laboratory analysis. Consequently, many of these cases remain undetected and the milk is delivered to the dairy. The most common way to detect subclinical mastitis is by analysing the somatic cell count (SCC) in milk from individual quarters, or cow composite milk. Bulk tank milk SCC is

*For correspondence; e-mail: Ase.Sternesjo@Imv.slu.se also an important parameter in quality programmes and milk payment systems of the dairy cooperatives. SCC is in many countries routinely analysed using automated fluoro-opto-electronic cell counting, which is a technology that is usually limited to central laboratories. Moreover, it has been difficult to adjust SCC analysis to the emerging automated milking systems. Despite the wide use of SCC, much effort has been invested in the search for alternative biomarkers for diagnosis of mastitis as well as for evaluation of its consequences in terms of compositional changes of the milk (Korhonen \& Kaartinen, 1995). Although SCC is closely linked to changes in the biochemical composition of the milk at quarter milk level (Hamann, 2005), SCC is 
a less sensitive or specific indicator of milk quality in bulk tank milk (Le Roux et al. 2003).

In human medicine, the acute phase proteins (APP) have become important diagnostic biomarkers of disease, and they are also being evaluated for use in veterinary medicine (Gruys et al. 1994; Eckersall et al. 2001; Grönlund et al. 2003; Pyörälä, 2003; Eckersall, 2004; Murata et al. 2004; Petersen et al. 2004; Grönlund et al. 2005). The major APP in cattle are haptoglobin (Hp) and serum amyloid $A(S A A)$, and serum concentrations of these mostly hepatically produced proteins increase dramatically upon a number of stimuli (Eckersall \& Conner, 1988; Alsemgeest et al. 1994; Horadagoda et al. 1999; Grönlund et al. 2003). Whereas elevated serum concentrations of $\mathrm{Hp}$ and SAA are generally regarded as nonspecific markers of inflammation, their presence in milk may provide specific information on the inflammatory status of the udder (Eckersall et al. 2001). Moreover, recent research has shown that in addition to hepatically produced $\mathrm{Hp}$ and SAA there is extrahepatic production in various tissues, including mammary epithelial cells (Hiss et al. 2004; McDonald et al. 2001).

Most studies of the occurrence of $\mathrm{Hp}$ and SAA in milk focus on experimentally induced mastitis and authors in general report increased concentrations of the proteins during the clinical stage of the disease (Horadagoda et al. 1999; Eckersall et al. 2001; Grönlund et al. 2003; Nielsen et al. 2004). Some studies also relate to milk from clinically healthy cows (Eckersall et al. 2001; Grönlund et al. 2003; Nielsen et al. 2004; Grönlund et al. 2005; Lindmark-Månsson et al. 2005; Eckersall et al. 2006; O'Mahony et al. 2006), while only a few studies relate to milk from subclinical mastitis (Grönlund et al. 2005; Eckersall et al. 2006; O'Mahony et al. 2006). Eckersall et al. (2001) compared the concentrations of $\mathrm{Hp}$ and SAA in milk from clinically healthy dairy cows and from cows with clinical mastitis of varying severity. For both proteins, milk levels were higher in the infected quarter than in milk from healthy quarters. For SAA, but not for $\mathrm{Hp}$, a relationship between the concentrations in milk and the severity of the mastitis was observed. Grönlund et al. (2003) studied the dynamics of $\mathrm{Hp}$ and SAA as experimentally induced mastitis passed from the acute clinical to the chronic subclinical phase. Changes in SAA and $\mathrm{Hp}$ were measured in milk samples from both the infected and control udder quarters and milk from the affected quarters contained significantly elevated SAA levels also during the subclinical phase. In another study, $\mathrm{Hp}$ and SAA in quarter milk samples from cows with chronic subclinical mastitis were compared with milk from quarters of healthy control cows (Grönlund et al. 2005). Udder quarters with chronic subclinical mastitis showed a substantial variation in $\mathrm{Hp}$ and SAA whereas levels below the detection limit were considered good indicators of healthy udder quarters. Nielsen et al. (2004) found a significant increase in $\mathrm{Hp}$ and SAA in quarter milk with increasing CMT (California Mastitis Test) score, and O'Mahony et al. (2006) also reported good, general correlation between SAA and SCC in quarter milk samples.

Studies so far have mainly focused on individual udder quarters, and the diagnostic value of $\mathrm{Hp}$ and SAA in comparison with existing standards, i.e., SCC. Studies usually contain a limited number of cows, and few studies concentrate on clinically healthy quarters. Today, the cow composite milk SCC is often used in evaluation of cow udder health. The influence of APP in individual udder quarters on the occurrence of APP in the cow composite milk sample therefore needs further investigation. For such studies, true, representative cow composite milk samples are needed for an accurate evaluation. In addition, the tank milk SCC is used to assess udder health and milk quality at herd level. However, no studies have been reported on the occurrence of $\mathrm{Hp}$ and SAA in bulk tank milk in relation to SCC.

The aim of the present study was to investigate relationships between $\mathrm{Hp}, \mathrm{SAA}$ and SCC in milk from clinically healthy cows at quarter, cow composite, and bulk tank level.

\section{Materials and Methods}

\section{Milk samples}

Cows were from two University dairy farms and from one private dairy farm in the region of Uppsala. They were of the two main Swedish dairy breeds, Swedish Red and White, and Swedish Holstein. They were tethered in tie stalls and fed according to Swedish recommendations. Cows were milked twice a day, were in lactation number 1-5 (median of 2) and lactation week 2-63 (median of 26), and produced $4-59 \mathrm{~kg}$ milk/d (median of 31). All cows in the herds $(n=78,61$ and 26 , respectively) delivering milk to the dairy at the sampling occasion were included in the study. Cows were considered clinically healthy; i.e., had neither clinical signs of disease nor abnormalities in the udder or in the milk. Cow composite milk samples were taken once from all cows in the three herds. From one farm, quarter milk samples $(n=103)$ were also collected from 26 cows. Cows were milked with a milking machine, designed to allow milk from each quarter to be collected separately during the entire milking. Separate quarter milk samples were taken, and then the milk from all four quarters was mixed and a representative cow composite milk sample taken. After SCC analysis, milk samples were frozen and stored at $-70{ }^{\circ} \mathrm{C}$ until analysis of $\mathrm{Hp}$ and SAA. In addition, bulk tank milk samples from 96 dairy farms were included in the study. These samples were obtained from and selected at Steins laboratory $A B$, Jönköping, to obtain samples within a wide range of SCC (38000-792000 cells/ml). After SCC analysis, milk samples were frozen at $-20{ }^{\circ} \mathrm{C}$ and delivered frozen to the University, where they were stored at $-70{ }^{\circ} \mathrm{C}$ until analysis of $\mathrm{Hp}$ and SAA. 


\section{Milk somatic cell count}

SCC was measured in fresh milk by fluoro-opto-electronic cell counting (Fossomatic 5000, Foss electric, Hillerød, Denmark).

\section{Milk haptoglobin}

Analysis of $\mathrm{Hp}$ was performed according to a recently described biosensor assay (Åkerstedt et al. 2006) with some minor modifications. In short, the developed method is based on the strong interaction between $\mathrm{Hp}$ and haemoglobin. The milk sample is mixed with bovine haemoglobin before injection over a sensor surface with covalently bound Hp. When there is no, or only small amounts of $\mathrm{Hp}$ present in the sample, haemoglobin will bind to immobilized $\mathrm{Hp}$ on the sensor surface. When $\mathrm{Hp}$ is present in the sample, it will form a complex with added haemoglobin, inhibiting haemoglobin binding to the surface. The biosensor response is inversely proportional to the amount of $\mathrm{Hp}$ in the sample. In the modified assay, the concentration of added haemoglobin was $1.5 \mathrm{mg} / \mathrm{l}$ and the contact time $75 \mathrm{~s}$, instead of $2.5 \mathrm{mg} / \mathrm{l}$ and $60 \mathrm{~s}$, respectively, in the original assay. Whole milk samples were analysed and the human 2-2 form of $\mathrm{Hp}$ (Sigma, St Louis MO 63178, USA) was used for immobilization and standards. The limit of detection (LOD) of the assay was $1 \mathrm{mg} / \mathrm{l}$.

\section{Milk serum amyloid $A$}

A commercial ELISA (Phase ${ }^{\mathrm{TM}}$ Serum Amyloid A Assay, Tridelta Development Ltd, Wicklow, Ireland) was used to determine SAA concentration in milk. Whole milk samples were initially diluted $1: 50$, and samples with an optical density above the range of the standard curve were further diluted and re-analysed. Optical densities were read on an automatic plate reader (Model ELx 800; Bio-tek Inc, Winooski VT, USA) at $450 \mathrm{~nm}$ with a reference at $630 \mathrm{~nm}$. The LOD of the ELISA was $0.3 \mathrm{mg} / \mathrm{l}$ according to the manufacturer.

\section{Statistical analyses}

Relationships between Hp, SAA and SCC at quarter, composite and bulk tank level were tested with Chi-square using SAS (Version 9.1, SAS Institute Inc., Cary NC, USA). Samples were categorized into five groups according to their SCC, i.e., <100 000; 101 000-200000; $201000-$ 300000 ; $301000-400000$; and $>400000 \mathrm{cells} / \mathrm{ml}$. For $\mathrm{Hp}$ and SAA, samples were categorized as below or above LOD, i.e., $1.0 \mathrm{mg} / \mathrm{l}$ and $0.3 \mathrm{mg} / \mathrm{l}$ respectively.

\section{Results}

In quarter milk samples, significant relationships were found between $\mathrm{Hp}$ and SCC $(P<0 \cdot 0001)$, SAA and SCC $(P<0.0001)$ and $\mathrm{Hp}$ and SAA $(P=0 \cdot 0028)$. Figure $1 \mathrm{a}$ shows the SCC $v$. Hp and SAA, respectively. Average SCC in the samples was $366757 \pm 190284$ cells $/ m$ lmedian 46000 cells $/ \mathrm{ml})$. Hp $(>1 \mathrm{mg} / \mathrm{l})$ was found in 9 out of 103 quarter milk samples (9\%) and the average Hp concentration in these samples was $7 \cdot 8 \pm 6 \cdot 4 \mathrm{mg} / \mathrm{l}$ (median $5 \cdot 3 \mathrm{mg}$ / I). For SAA, 54 out of 103 quarter milk samples (52\%) contained SAA $(>0.3 \mathrm{mg} / \mathrm{l})$ and the average SAA concentration in these samples was $7 \cdot 6 \pm 12 \cdot 1 \mathrm{mg} / \mathrm{l}$ (median $2.5 \mathrm{mg} / \mathrm{l})$. In 7 of the 26 cows $(27 \%)$, both $\mathrm{Hp}$ and SAA concentrations were below LOD in all quarters. Average cow composite SCC for these cows was $31000 \pm$ 18000 cells $/ \mathrm{ml}$. Average SCC in the corresponding cow composite milk sample of quarters with detectable $\mathrm{Hp}$ and/ or SAA concentrations was $511000 \pm 965000$ cells $/ \mathrm{ml}$. In these samples, concentrations of $\mathrm{Hp}$ and SAA varied markedly between the quarters and to illustrate this, results for 10 of the 19 cows are shown in Table 1.

In the cow composite milk samples, significant relationships were found between $\mathrm{Hp}$ and SCC $(P<0 \cdot 0001)$, between SAA and SCC $(P<0.0001)$ and $\mathrm{Hp}$ and SAA $(P=0 \cdot 0008)$. SCC $v$. Hp and SAA in composite milk samples is illustrated in Fig. 1b. Average SCC for the composite milk samples was $187127 \pm 427153 \mathrm{cell} / \mathrm{ml}$ (median 70000 cells $/ \mathrm{ml}$ ). Hp was found in 28 out of 165 composite milk samples (17\%), and the average $\mathrm{Hp}$ concentration in these samples was $2 \cdot 6 \pm 3 \cdot 1 \mathrm{mg} / \mathrm{l}$ (median $1.5 \mathrm{mg} / \mathrm{l})$, while 82 out of 165 samples (50\%) contained detectable amounts of SAA. Average SAA concentration in these samples was $5 \cdot 6 \pm 13 \cdot 0 \mathrm{mg} / \mathrm{l}$ (median $2 \cdot 2 \mathrm{mg} / \mathrm{l}$ ).

In bulk tank milk samples, a significant relationship was found between SAA and SCC $(P=0 \cdot 0013)$, but not between Hp and SCC $(P=0.15)$ or Hp and SAA $(P=0.96)$. In Fig. 1C, the SCC $v$. Hp and SAA in bulk tank milk samples is presented. Average SCC was $268896 \pm 142527$ cells $/ \mathrm{ml}$ (median 258000 cells/ml) for the 96 samples in this study. Hp was found in 39 out of 96 bulk tank milk samples $(41 \%)$ and the average Hp concentration in these samples was $1.5 \pm 0.6 \mathrm{mg} / \mathrm{l}$ (median 1.3). For bulk tank milk samples, 79 of 96 (82\%) contained SAA, and the average SAA concentration in those samples was $2 \cdot 0 \pm 1.5 \mathrm{mg} / \mathrm{l}$ (median 1·3).

In Table 2 the relationships between $\mathrm{Hp}$, SAA and SCC are summarized at quarter, cow composite and bulk tank milk levels.

\section{Discussion}

In the present study, $\mathrm{Hp}$ and SAA were present at detectable levels in milk at quarter, cow composite and bulk tank levels. To our knowledge, this is the first study reporting $\mathrm{Hp}$ and SAA levels in all four individual quarters in relation to the SCC using quarter and true cow composite milk samples representing the entire milk volume of one milking. In addition, this is, to our knowledge, the first report on $\mathrm{Hp}$ and SAA in bulk tank milk in relation to SCC. A large proportion of the animals in this study i.e. 88 out of 

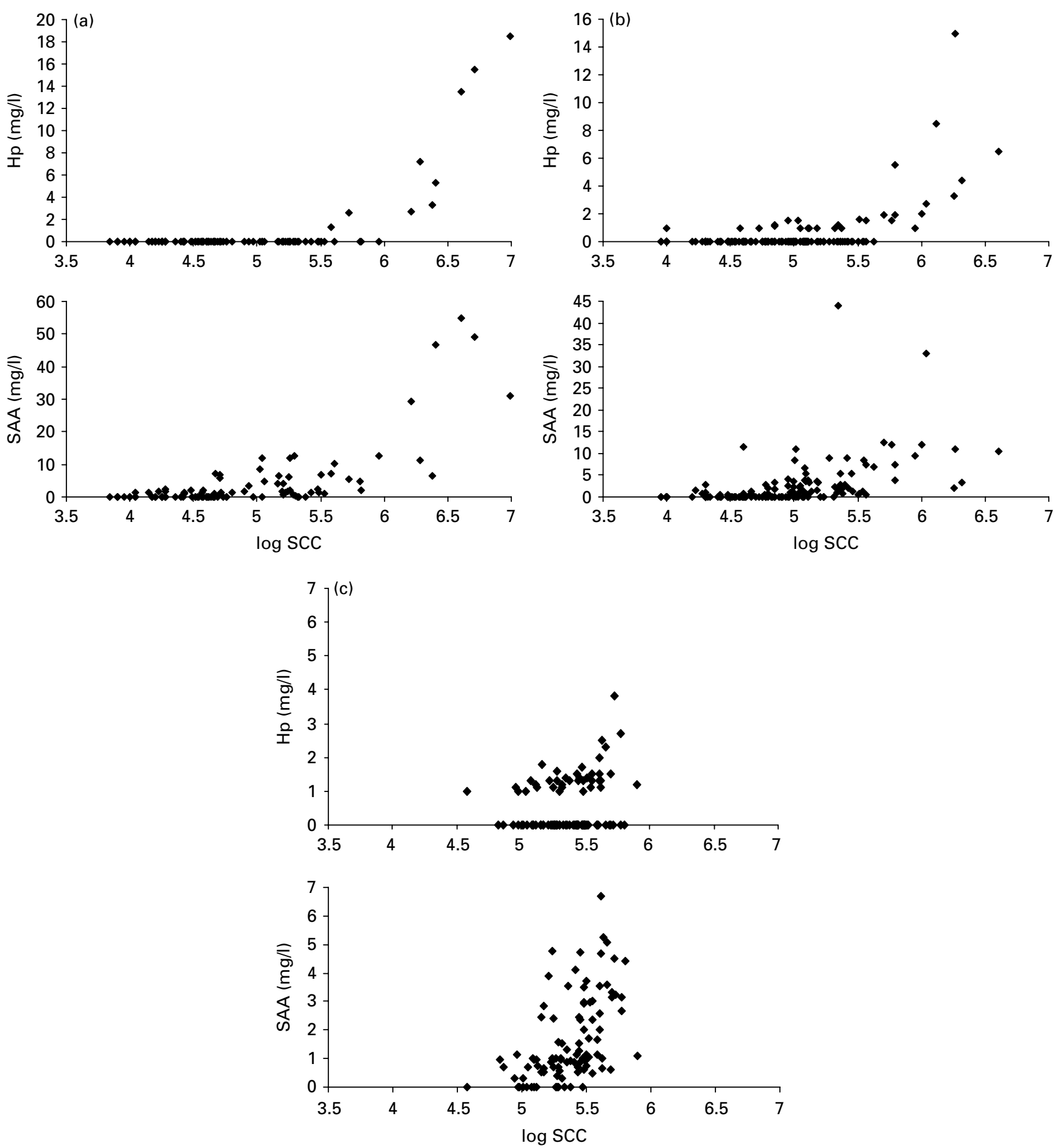

Fig. 1. Somatic cell count (SCC) $v$. haptoglobin ( $\mathrm{Hp}$ ) and serum amyloid A (SAA) concentrations in (a) quarter milk, (b) cow composite milk and (c) bulk tank milk samples.

165 cow composite milk samples (53\%) had detectable milk concentrations of $\mathrm{Hp}$ and/or SAA, even though all animals were considered clinically healthy. Regardless of sample type (quarter, cow composite and bulk tank) SAA was detected more frequently in the milk than $\mathrm{Hp}$, also when the results were adjusted for the lower detection limit of the SAA assay.
We found a significant relationship between SCC and SAA in quarter and composite milk samples, the presence of SAA was significantly more common in milk at higher SCC, in agreement with Lindmark-Månsson et al. (2005) and O'Mahony et al. (2006). Our study also demonstrated that the presence of $\mathrm{Hp}$ was significantly more common at higher SCC in quarter and composite milk samples in 
Table 1. Milk haptoglobin ( $\mathrm{Hp}$ ) and serum amyloid A (SAA) concentrations in udder quarters within cow, and in the composite milk in relation to the somatic cell count (SCC). The table shows results from 10 out of 19 cows with milk containing $\mathrm{Hp}$ and/or $\mathrm{SAA} . \mathrm{RF}=$ right fore, $\mathrm{RR}=$ right rear, $\mathrm{LF}=$ left fore, $\mathrm{LR}=$ left rear quarter

\begin{tabular}{|c|c|c|c|c|}
\hline Cow ID & $\begin{array}{l}\text { Udder } \\
\text { quarter }\end{array}$ & $\begin{array}{l}\text { SCC } \times \\
10^{-3} / \mathrm{ml}\end{array}$ & $\begin{array}{l}\mathrm{Hp}, \\
\mathrm{mg} / \mathrm{l}\end{array}$ & $\begin{array}{l}\mathrm{SAA}, \\
\mathrm{mg} / \mathrm{I}\end{array}$ \\
\hline \multirow[t]{5}{*}{861} & RF & 1914 & $7 \cdot 2$ & $11 \cdot 2$ \\
\hline & $\mathrm{RR}$ & 57 & $<t$ & $<$ \\
\hline & $\mathrm{LF}$ & 1618 & $2 \cdot 7$ & $29 \cdot 3$ \\
\hline & $\mathrm{LR}$ & 36 & $<$ & $0 \cdot 5$ \\
\hline & composite & 104 & $<$ & $0 \cdot 7$ \\
\hline \multirow[t]{5}{*}{867} & RF & 2375 & $3 \cdot 3$ & $6 \cdot 4$ \\
\hline & $\mathrm{RR}$ & 342 & $<$ & $1 \cdot 0$ \\
\hline & LF & 305 & $<$ & $1 \cdot 4$ \\
\hline & & 192 & $<$ & $0 \cdot 6$ \\
\hline & composite & 349 & $<$ & $1 \cdot 0$ \\
\hline \multirow[t]{5}{*}{891} & $\mathrm{RF}$ & 38 & $<$ & 1.9 \\
\hline & $\mathrm{RR}$ & 27 & $<$ & $1 \cdot 4$ \\
\hline & LF & 319 & $<$ & $6 \cdot 9$ \\
\hline & & 37 & $<$ & $1 \cdot 4$ \\
\hline & composite & 62 & $<$ & $2 \cdot 0$ \\
\hline \multirow[t]{5}{*}{896} & RF & 51 & $<$ & $5 \cdot 7$ \\
\hline & $\mathrm{RR}$ & 106 & $<$ & $8 \cdot 6$ \\
\hline & LF & 51 & $<$ & $6 \cdot 9$ \\
\hline & LR & 181 & $<$ & 11.9 \\
\hline & composite & 99 & $<$ & $7 \cdot 8$ \\
\hline \multirow[t]{5}{*}{897} & RF & 162 & $<$ & $4 \cdot 0$ \\
\hline & $\mathrm{RR}$ & 114 & $<$ & $4 \cdot 7$ \\
\hline & $\mathrm{LF}$ & 86 & $<$ & $3 \cdot 3$ \\
\hline & $\mathrm{LR}$ & 146 & $<$ & $4 \cdot 0$ \\
\hline & composite & 122 & $<$ & $4 \cdot 0$ \\
\hline \multirow[t]{5}{*}{936} & RF & 30 & $<$ & $2 \cdot 0$ \\
\hline & $\mathrm{RR}$ & 19 & $<$ & $1 \cdot 8$ \\
\hline & $\mathrm{LF}$ & 302 & $<$ & $2 \cdot 5$ \\
\hline & & 17 & $<$ & $1 \cdot 6$ \\
\hline & composite & 46 & $<$ & $1 \cdot 5$ \\
\hline \multirow[t]{5}{*}{992} & RF & 46 & $<$ & $1 \cdot 1$ \\
\hline & $\mathrm{RR}$ & 383 & $1 \cdot 3$ & $7 \cdot 1$ \\
\hline & LF & 27 & $<$ & $1 \cdot 1$ \\
\hline & $\mathrm{LR}$ & 52 & $<$ & $1 \cdot 4$ \\
\hline & composite & 124 & $<$ & $3 \cdot 2$ \\
\hline \multirow[t]{5}{*}{1020} & RF & 79 & $<$ & $1 \cdot 8$ \\
\hline & $\mathrm{RR}$ & 46 & $<$ & $<$ \\
\hline & $\mathrm{LF}$ & 64 & $<$ & $1 \cdot 3$ \\
\hline & $\mathrm{LR}$ & 31 & $<$ & $<$ \\
\hline & composite & 46 & $<$ & $0 \cdot 7$ \\
\hline \multirow[t]{5}{*}{1171} & RF & 19 & $<$ & $2 \cdot 5$ \\
\hline & $\mathrm{RR}$ & 2522 & $5 \cdot 3$ & $46 \cdot 6$ \\
\hline & LF & 918 & $<$ & $12 \cdot 7$ \\
\hline & LR & 178 & $<$ & $6 \cdot 0$ \\
\hline & composite & 887 & $1 \cdot 0$ & $9 \cdot 8$ \\
\hline \multirow[t]{5}{*}{1187} & RF & 182 & $<$ & $2 \cdot 0$ \\
\hline & $\mathrm{RR}$ & 33 & $<$ & $<$ \\
\hline & $\mathrm{LF}$ & 16 & $<$ & $<$ \\
\hline & $\mathrm{LR}$ & 19 & $<$ & $<$ \\
\hline & composite & 56 & $<$ & $<$ \\
\hline
\end{tabular}

tThe sample had a concentration lower than the limit of detection (LOD) of the assay; LOD for haptoglobin assay $=1 \mathrm{mg} / \mathrm{l}$ and for SAA assay $=0.3 \mathrm{mg} / \mathrm{l}$
Table 2. Relationships between somatic cell count (SCC) and the presence of haptoglobin $(\mathrm{Hp})$ and serum amyloid $\mathrm{A}(\mathrm{SAA})$ in quarter, cow composite and bulk tank milk samples. Values are $P$-values from the Chi-square analyses

$\begin{array}{llcl}\text { Milk sample } & \text { Hp/SCC } & \text { SAA/SCC } & \text { Hp/SAA } \\ \text { Quarter } & <0.0001 & <0.0001 & 0.0028 \\ \text { Cow composite } & <0.0001 & <0.0001 & 0.0008 \\ \text { Bulk tank } & \text { NSt } & 0.0013 & \text { NS }\end{array}$

$+N S$, not significant

agreement with Nielsen et al. (2004). Moreover, SAA, but not $\mathrm{Hp}$, was found more often in bulk tank milk samples with high SCC. As this is the first study reporting a relationship between APP and SCC in bulk tank milk, further studies are needed to confirm these results. Our results indicate that the relationship between SAA and SCC is stronger than that between $\mathrm{Hp}$ and SCC. When comparing our results with results from previous studies it is important to remember that the milk is not from clinical cases of mastitis but milk from clinically healthy cows. Due to a large number of observations without detectable concentrations of the proteins, chi-square and not correlation analysis was applied for statistical evaluation. This is also important to have in mind when comparing our results with those of others. In our study, SAA was found more frequently and at higher levels, than $\mathrm{Hp}$ at quarter level. The dilution that takes place from quarter to bulk tank could be one reason why we found no relationship between $\mathrm{Hp}$ and SCC in bulk tank milk. The finding of SAA in as many as $50 \%$ of the cow composite milk samples and $82 \%$ of the bulk tank milk samples is surprisingly high.

SAA is an apolipoprotein (Malle et al. 1993; Uhlar \& Whitehead, 1999) and it is likely that the main part of the protein will be found in association with the milk fat. Thus, we believe it is important to use whole milk samples instead of defatted milk, which was the case in the present study and in the study by Grönlund et al. (2005). Moreover, in earlier studies (Nielsen et al. 2004; Grönlund et al. 2005; Jacobsen et al. 2005; O'Mahony et al. 2006) representative quarter, and cow composite samples were not used. During milking, the milk fat content varies between milk fractions, which may influence the SAA concentration. Moreover, pooling equal volumes of milk from quarter samples into a cow composite sample will not reflect differences in milk volumes between the quarters, and this may also affect the levels of APP observed in the cow composite sample. In contrast to other studies, we used presence, or no presence, of APP instead of the actual concentration when studying their relationships with the $\mathrm{SCC}$, as the knowledge related to biologically relevant cut-off levels in milk is limited.

In our study, presence of SAA in one or more quarters was occasionally associated with elevated SCC, but not always. An intramammary inflammation in one or more quarters as indicated by an elevated SCC could in several 
cases be detected by the presence of SAA in the cow composite sample, although this was not always reflected in the cow composite milk SCC (Table 1). In several cows SAA was detected in all four quarters and in the cow composite sample, despite a normal cow composite SCC. According to Grönlund et al. (2003) and Nielsen et al. (2004) significantly elevated levels of $\mathrm{Hp}$ and SAA were found in infected quarters. However, in both studies, SAA but not Hp was also detected in some control quarter samples. Likewise, in a study on experimental subclinical mastitis (Eckersall et al. 2006) the authors found SAA in some of the control quarters. During certain physiological conditions, such as at dry-off and oestrus, the permeability of the blood/milk barrier is increased resulting in leakage of blood proteins into milk. Thus, if APP levels in serum are increased due to non-mastitic conditions, their content in milk may increase independently of the SCC. To increase the understanding of relationships between $\mathrm{Hp}, \mathrm{SAA}$ and SCC in milk, the importance of such physiological variation needs to be investigated.

In conclusion, we found $\mathrm{Hp}$ and SAA in quarter and cow composite milk samples from clinically healthy animals and in bulk tank milk delivered to the dairies. There were significant relationships between Hp, SAA and SCC at quarter and cow composite milk levels, and between SAA and SCC at bulk tank milk level with detectable levels of APP being more frequent at increasing SCC. This is the first study reporting the occurrence of detectable levels of APP in bulk tank milk and further studies should focus not only on the potential of using $\mathrm{Hp}$ and SAA as markers for subclinical mastitis, but also on their effects on milk composition and processing properties.

The authors thank the Swedish Farmers' Foundation for Agricultural Research for financial support. We also thank Lotta Wall at the Department of Food Science, Anna-Karin Båvius at the Department of Animal Nutrition and Management for technical assistance, and Lars Eriksson and Ewa Mellin at Högby farm, Uppsala-Näs, for kindly allowing the use of their herd in this study.

\section{References}

Åkerstedt M, Björck L, Persson Waller K \& Sternesjö Å 2006 Biosensor assay for determination of haptoglobin in bovine milk. Journal of Dairy Research 73 299-305

Alsemgeest SPM, Kalsbeek HC, Wensing T, Koeman JP, Vanederen AM \& Gruys E 1994 Concentrations of serum Amyloid-A (SAA) and Haptoglobin $(\mathrm{Hp})$ as parameters of inflammatory diseases in cattle. Veterinary Quarterly 16 21-23

Eckersall PD 2004 The time is right for acute phase protein assays. Veterinary Journal 168 3-5

Eckersall PD \& Conner JG 1988 Bovine and canine acute phase proteins. Veterinary Research Communications 12 169-178

Eckersall PD, Young FJ, McComb C, Hogarth CJ, Safi S, Weber A, McDonald T, Nolan AM \& Fitzpatrick JL 2001 Acute phase proteins in serum and milk from dairy cows with clinical mastitis. Veterinary Record 148 35-41

Eckersall PD, Young FJ, Nolan AM, Knight CH, McComb C, Waterston MM, Hogarth CJ, Scott EM \& Fitzpatrick JL 2006 Acute phase proteins in bovine milk in an experimental model of Staphylococcus aureus subclinical mastitis. Journal of Dairy Science 89 1488-1501

Grönlund U, Hulten C, Eckersall PD, Hogarth C \& Waller KP 2003 Haptoglobin and serum amyloid $\mathrm{A}$ in milk and serum during acute and chronic experimentally induced Staphylococcus aureus mastitis. Journal of Dairy Research 70 379-386

Grönlund U, Sandgren CH \& Waller KP 2005 Haptoglobin and serum amyloid A in milk from dairy cows with chronic subclinical mastitis. Veterinary Research 36 191-198

Gruys E, Obwolo MJ \& Toussaint MJM 1994 Diagnostic significance of the major acute phase proteins in veterinary clinical chemistry: a review. Veterinary Bulletin 64 1009-1018

Hamann J 2005 Diagnosis of mastitis and indicators of milk quality. In Mastitis in Dairy Production. Wageningen, The Netherlands: Wageningen Academics Publishers

Hiss S, Mielenz M, Bruckmaier RM \& Sauerwein H 2004 Haptoglobin concentrations in blood and milk after endotoxin challenge and quantification of mammary Hp mRNA expression. Journal of Dairy Science 87 3778-3784

Horadagoda NU, Knox KMG, Gibbs HA, Reid SWJ, Horadagoda A, Edwards SER \& Eckersall PD 1999 Acute phase proteins in cattle: discrimination between acute and chronic inflammation. Veterinary Record 144 437-441

Jacobsen S, Niewold TA, Kornalijnslijper E, Toussaint MJM \& Gruys E 2005 Kinetics of local and systemic isoforms of serum amyloid A in bovine mastitic milk. Veterinary Immunology and Immunopathology $10421-31$

Korhonen H \& Kaartinen L 1995 Changes in the composition of milk induced by mastitis. In The Bovine Udder and Mastitis, pp. 76-82 (Eds M Sandholm, T Honkanen-Buzalski, L Kaartinen \& S Pyörälä). Jyväskylä, Finland: Gummerus Kirjapaino

Le Roux Y, Laurent F \& Moussaoui F 2003 Polymorphonuclear proteolytic activity and milk composition change. Veterinary Research 34 629-645

Lindmark-Månsson H, Bränning C, Aldén G \& Paulsson M 2006 Relationship between somatic cell count, individual leukocyte populations and milk components in bovine udder quarter milk. International Dairy Journal 16 717-727

Malle E, Steinmetz A \& Raynes JG 1993 Serum amyloid A (SAA) : an acute phase protein and apolipoprotein: a review. Atherosclerosis 102 131-146

McDonald TL, Larson MA, Mack DR \& Weber A 2001 Elevated extrahepatic expression and secretion of mammary-associated serum amyloid A 3 (M-SAA3) into colostrum. Veterinary Immunology and Immunopathology 83 203-211

Murata H, Shimada N \& Yoshioka M 2004 Current research on acute phase proteins in veterinary diagnosis: an overview. Veterinary Journal $16828-40$

Nielsen BH, Jacobsen S, Andersen PH, Niewold TA \& Heegaard PMH 2004 Acute phase protein concentrations in serum and milk from healthy cows, cows with clinical mastitis and cows with extramammary inflammatory conditions. Veterinary Record 154 361-365

O'Mahony MC, Healy AM, Harte D, Walshe KG, Torgerson PR \& Doherty ML 2006 Milk amyloid A: Correlation with cellular indices of mammary inflammation in cows with normal and raised serum amyloid A. Research In Veterinary Science 80 155-161

Petersen HH, Nielsen JP \& Heegaard PMH 2004 Application of acute phase protein measurements in veterinary clinical chemistry. Veterinary Research 35 163-187.

Pyörälä S 2003 Indicators of inflammation in the diagnosis of mastitis. Veterinary Research 34 565-578

Uhlar CM \& Whitehead AS 1999 Serum amyloid A, the major vertebrate acute-phase reactant. European Journal of Biochemistry 265 501-523 